Serum and Vaccine Research Institute, Abbassia, Cairo,

Head Prof. Dr. S. Salama.

\title{
STUDIES ON INFECTIOUS LARYNGOTRACHEITIS VIRUS VACCINE II- THE EFFECT OF INCUBATION TEMPERATURE \\ ON THE PATHOGENICITY OF I.L.T. VIRUS (FOR CHICKEN EMBRYOS INOCULATED BY THE ALLANTOIC SAC ROUTE) (With 2 Tables)
}

By

SUSAN TOLBA, I. REDA; SALWA EL-ASELY; ELHAM EL-EBIARY; A. EL-SONOSI and NARGES BARHAUMA (Received at 10/6/1990)

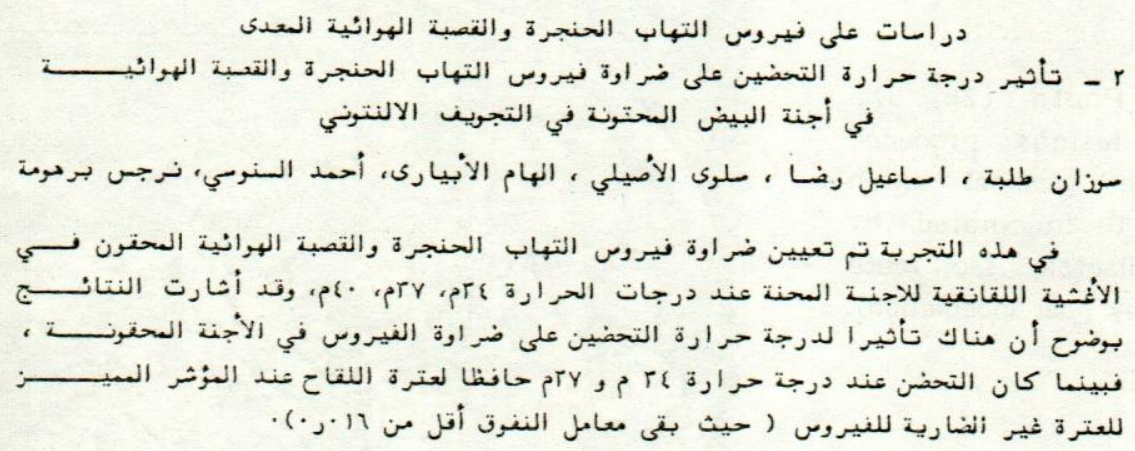

\section{SUMMARY}

The incubation of chicken embryos inoculated with original vaccinal strain at different temperature $34^{\circ} \mathrm{C}, 37^{\circ} \mathrm{C}$ and $40^{\circ} \mathrm{C}$ had a considerable influence on the pathogenicity of virus inoculated embryos:

1- The mortality index for chicken embryos (MICE) of the original vaccinal strain when the embryos were incuabted at $34^{\circ} \mathrm{C}, 37^{\circ} \mathrm{C}$ and $40^{\circ} \mathrm{C}$ were $0.072,0.028$ and 0.46 respectively.

2- One passage of thevirus at $34^{\circ} \mathrm{C}$ kept thevirus pathogenicity at an indices of $0.05,0.067$ and 0.166 for temperatures of $34^{\circ} \mathrm{C}, 37^{\circ} \mathrm{C}$ and $40^{\circ} \mathrm{C}$ respectively.

3- One passage of the virus at $37^{\circ} \mathrm{C}$ resulted in pathogenicity indices of $0.06,0.029$ and 0.45 for $34^{\circ} \mathrm{C}, 37^{\circ} \mathrm{C}$ and $40^{\circ} \mathrm{C}$ and $40^{\circ} \mathrm{C}$ respectively.

4- One passage of the virus at $40^{\circ} \mathrm{C}$ resulted in a virus which showed MICE of 0.11 and 0.44 when embryos were incubated at $34^{\circ} \mathrm{C}$, $37^{\circ} \mathrm{C}$ and $40^{\circ} \mathrm{C}$ respectively.

Assiut Vet.Med.J. Vol. 25, No. 49, April, 1991. 
SUSAN TOLBA et al.

\section{INTRODUCTION}

Infetious laryngotracheitis virus (I.L.T.) is an acute respiratory disease of adult chicken group-A herpes virus (MOTTANTY and DUTTA, 1981). susceptible chickens of all ages may be affected.

ILT was considered to be exotic disease for Egypt since 1982 (TANTAWI et al., 1983). Repeated virus isolation and serosurvy studies have proved the wide spread existance of clinical and subclinical forms of the disease among laying and broiler flocks (AMER, 1984 and ABD-SALAM, 1986).

The production of efficient and safe live modified virus vaccine locally for ILT is of great importance and the present study aimed to investigate the effect of incubation temperature on the pathogenicity of ILT virus for chicken embryos inoculated via allantoic route. The importance of this study lies in the fact that changes in temperature for few degree higher than that commonly $37^{\circ} \mathrm{C}$ for incubation of infected embryos could have a series effect on the virulence of the virus and consequantly on the quality of produced vaccine.

\section{MATERIAL and METHODS}

\section{Materials :}

1. Embryonated chicken eggs $7-12$ th days of age for virus titration and isolation, supplied by poultry organization.

2. Vaccinal strain of ILT virus, a modified adapted Ivie and lyophilized virus vaccine produced in specific pathogen free obtained from a well known commercjal firm (by TAD-pharmacutisches WERK GMBH). Each ampoul (1000 doses) contain $10^{6.4}$ $E_{50}$ of vaccinal strain. It was kept at $4^{\circ} \mathrm{C}$ till it's use.

3. Saline, antibiotics, tincture iodine.

\section{Methods}

1. Virus titration: Serial tenfold dilutions starting from $10^{-1}$ till $10^{-10}$ were made from the vaccinal strain in sterile PBS. Calculation of $50 \%$ embryos infective dose (EID ${ }_{50}$ ) was according to REED and MUENCH (1938).

2. Determination of virus pathogenicity: $10^{-3} \mathrm{EID}_{50} / \mathrm{ml}$ of virus strains to be tested inoculated in 11 days old chicken embryos via allantoic cavity with $0.1 \mathrm{ml}$ using 15 eggs for each strain incubated at $37^{\circ} \mathrm{C}$. (The CMICE) mortality index for chicken embryos was calulated according to (IZUCHI and HASEGAWA, 1982). et al., 1985).

3. Virus isolation: it was performed on chorio-allantoic membrane (HITCHNER

\section{EXPERIMENTAL DISIGN:}

(A) Determination of the pathogenicity of vaccinal strains for chicken embryos under different incubation period.

(B) Determination of the pathogenicy of ILT-virus in CAM of embryos which have

Assiut Vet.Med.J. Vol. 25, No. 49, April, 1991. 
1. T, Pathogenicity

been incubated at different temeprature with $0.1 \mathrm{ml}$ of $10^{-3}-10^{-4} \mathrm{EID}_{50} / \mathrm{ml}$ and then divided into 3 groups each containing 15 embryos andincubated at the above mentioned temperature.

\section{RESULTS}

The reults of the influence of the pathogencity of ILT-virus for chicken embryos according to different incubation temperature was shown in table (1). From the table it is cleared that the original vaccine virus had a mortality index for chicken embryos (NICE) of $0.072,0.028$ and 0.46 when embryos were incubted at $34^{\circ} \mathrm{C}, 37^{\circ} \mathrm{C}$ and $40^{\circ} \mathrm{C}$ respectively.

Table (2) shows the influence of the pathogenicity of ILT-virus in CAM of embryos which have been indubated at different temperature $\left(34^{\circ} \mathrm{C}-37^{\circ} \mathrm{C}\right.$ and $40^{\circ} \mathrm{C}$ ) and collected 5 days post inoculation from this table we can notice that one passage of the virus at $34^{\circ} \mathrm{C}$ kept the virus pathogencity at an indices of $0.05,0.067$ and 0.166 for temperature of $34^{\circ} \mathrm{C}, 37^{\circ} \mathrm{C}$ and $40^{\circ} \mathrm{C}$ rspectively. One passage of thevirus at $37^{\circ} \mathrm{C}$ resulted in pathogenicity indices of $0.06,0.029$ and 0.45 for $34^{\circ} \mathrm{C}, 37^{\circ} \mathrm{C}$ and $40^{\circ} \mathrm{C}$ respectively. One passag of the vacinal strain virus at $40^{\circ} \mathrm{C}$ resulted in a virus which showed MICE of $0.11,0.18$ and 0.44 when embryos were incubated at $34^{\circ} \mathrm{C}, 37^{\circ} \mathrm{C}$ and $40^{\circ} \mathrm{C}$ respectively. Also the rsults show that the inoculated eggs kept at $40^{\circ} \mathrm{C}$ resulted in higher embryos mortalities if compared to the other temeprture $\left(34^{\circ} \mathrm{C}\right.$ and $\left.37^{\circ} \mathrm{C}\right)$.

\section{DISCUSSION}

ILT was considered to be an exotic disease for Egypt since 1982, the country was attacked by a serious outbreak of this disease which spread rapidly to cover several ares in Egypt. Loses were enormous, mortality reached as high as 19.9 and egg production was lowered 35\% in some flocks (TANTAWI et al., 1983). Since the ILT-virus infection occurred among Egyptian poultry farms this needed scientifically based vaccination and control programs.

In this study trials were made to determine the effect of temperature of incubation on virus yield and pathogenicity on the keeping quality of harvested virus. The results as shown in table (1) clear that the incubation of the chicken embryos incubated with the original vaccinal strain at different temperature $34^{\circ} \mathrm{C}, 37^{\circ} \mathrm{C}$ and $40^{\circ} \mathrm{C}$ had a considerable influence on the pathogenicity of th virus in inoculated embryos. Thus while the incubation at $34^{\circ} \mathrm{C}$ and $37^{\circ} \mathrm{C}$ kept the vaccinal strain at indices characteristic for a virulent ILT virus strain (less than 0.16 ). The (MICE) mortality index for chicken embryos was calculated according to (IZUCHI and HASEGAWA, 1982), results of these authors suggested that strain with MICE more than 0.27 would be highly pathogenic.

The keeping of incubated eggs at $40^{\circ} \mathrm{C}$ resulted in higher embryo morlatities giving rise to an index of 0.46 which was clearly denoting an increase of virus pathogenicity indices from that determined for the original vaccinal virus, yet passage of

Assiut Vet.Med.J. Vol. :-, No. 49, April, 1991. 


\section{SUSAN TOLBA et al.}

virus once at $40^{\circ} \mathrm{C}$ had resulted in higher pathogencity indices even when in the second time the virus was kept (for a second time) at $40^{\circ} \mathrm{C}$ didn't change the MICE and remined by 0.44 . The importance of these results lie in the fact that, a change in the temperture for few degrees higher than that commonly used $\left(37^{\circ} \mathrm{C}\right)$ for incubation of infected embryos, a matter which may occure accidently, would have a serious effect on the quality of the produced vaccine in the direction of its pathogenicity to chiken embryos. this later may be a reflection to its increased virulence to the chickens.

\section{REFERENCES}

Abd-Salam, M. (1986): Studies on the epidemiology of ILT in poultry in Egypt. M.T.Sc. Thesis, Fac. Vet. Med. Cairo Univ.

Amer, M.M. (1984): Evalaution of emergency vaccination in case of outbreaks of Newcastle disease. Ph.D. Thesis, Fac. Vet. Med. Cairo Univ.

Hitchner, S.B.; Gatherine, A. Shea and White, P.G. (1958): Studies on a serum neutralization test for the diagnosis of ILT chickens. Avian disease, 2, 258-269.

Reed, L.J. and Muench, H. (1938): A simple method of estimating fifty percent and point. Am. J., Hyg. 27, 493-497.

Izuchi, T. and A. Hasegawa (1982): Pathogenicity of ILT virus as measured by chicken embryo inoculation. Avian disease. 26: 18-25.

Mohanty, S.B. and Dutta, S.K. (1981): Nature and classification of viruses veterinary virology, P. 14-15. Published by Lea Febiger Philadelphia.

Tantawi, H.H.; El-Batrawi, A.M. Bastami, M.A. Youssef, Y.l. and Fawzia, M.M. (1983): Avian ILT in Egypt. 1- Epidemiology virus isolation and identification. Vet. Res. Communications, 6(4): 281-287.

Table (1): Studies on the pathogenicity of the original vaccinal strain of ILt virus for chicken embryos incubated at different temperature.

\begin{tabular}{|c|c|c|c|c|c|c|c|c|c|c|}
\hline \multirow[t]{2}{*}{ Sample } & \multirow{2}{*}{$\begin{array}{l}\text { Status of } \\
\text { embryos }\end{array}$} & \multicolumn{6}{|c|}{ No. of embryo on day/PI } & \multirow{2}{*}{\multicolumn{2}{|c|}{$\begin{array}{l}\text { Cumu- } \\
\text { lative } \\
\text { No. }\end{array}$}} & \multirow[t]{2}{*}{ •MICE } \\
\hline & & 1 & 2 & 3 & 4 & 5 & 6 & & & \\
\hline \multirow[t]{2}{*}{$34^{\circ} \mathrm{C}$} & dead & - & - & - & 1 & 1 & 2 & 4 & 8 & \\
\hline & a live & 15 & 15 & 15 & 14 & 14 & 13 & 11 & 97 & 0.073 \\
\hline \multirow[t]{2}{*}{$37^{\circ} \mathrm{C}$} & dead & - & - & - & - & - & + & 2 & 3 & \\
\hline & a live & 15 & 15 & 15 & 15 & 15 & 14 & 13 & 102 & 0.028 \\
\hline \multirow[t]{2}{*}{$40^{\circ} \mathrm{C}$} & dead & - & - & 2 & 4 & 7 & 11 & 14 & 38 & \\
\hline & a live & 15 & 15 & 13 & 11 & 8 & 4 & 1 & 82 & 0.46 \\
\hline
\end{tabular}

Assiut Vet_Med.J. Vol: 25, No. 49, April, 1991. 


\section{ILT, Pathogenicity}

Table (2) Effect of temperature on the pathogenicity of ILT in CAM of embryos

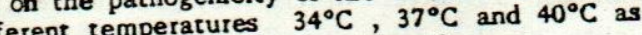
which have been incubated at different temperateres by in allantoic sac.

\begin{tabular}{|c|c|c|c|c|c|c|c|c|c|c|}
\hline Sample & $\begin{array}{l}\text { Status } \\
\text { of } \\
\text { embryos }\end{array}$ & 1 & $\begin{array}{l}\text { No. } \\
2\end{array}$ & of en & bryos & $s$ on & day PI & 7 & $\begin{array}{l}\text { Cumul- } \\
\text { alive No. } \\
\text { of embryos }\end{array}$ & MICE \\
\hline $\begin{array}{l}\text { Group } 34^{\circ} \mathrm{C} \\
34^{\circ} \mathrm{C}\end{array}$ & $\begin{array}{l}\text { Dead } \\
\text { a live }\end{array}$ & $\begin{array}{c}0 \\
15\end{array}$ & $\begin{array}{c}0 \\
15\end{array}$ & $\begin{array}{c}0 \\
15\end{array}$ & $\begin{array}{c}0 \\
15\end{array}$ & $\begin{array}{l}0 \\
15\end{array}$ & $\begin{array}{l}2 \\
13\end{array}$ & $\begin{array}{l}3 \\
12\end{array}$ & $\begin{array}{l}5 \\
100\end{array}$ & 0.05 \\
\hline $37^{\circ} \mathrm{C}$ & $\begin{array}{l}\text { Dead } \\
\text { a live }\end{array}$ & $\begin{array}{l}0 \\
15\end{array}$ & $\begin{array}{l}0 \\
14\end{array}$ & 13 & 13 & 13 & $\begin{array}{l}1 \\
13\end{array}$ & 3 & $\begin{array}{l}7 \\
92\end{array}$ & 0.076 \\
\hline $40^{\circ} \mathrm{C}$ & $\begin{array}{l}\text { Dead } \\
\text { a live }\end{array}$ & $\begin{array}{l}0 \\
15\end{array}$ & $\begin{array}{l}0 \\
15\end{array}$ & $\begin{array}{l}0 \\
15\end{array}$ & $\begin{array}{l}0 \\
15\end{array}$ & $\begin{array}{l}2 \\
13\end{array}$ & $\begin{array}{l}5 \\
10\end{array}$ & $\begin{array}{l}8 \\
7\end{array}$ & $\begin{array}{l}15 \\
90\end{array}$ & 0.166 \\
\hline $\begin{array}{l}\text { Group } 37^{\circ} \mathrm{C} \\
34^{\circ} \mathrm{C}\end{array}$ & $\begin{array}{l}\text { Dead } \\
\text { a live }\end{array}$ & $\begin{array}{l}0 \\
15\end{array}$ & $\begin{array}{l}0 \\
15\end{array}$ & $\begin{array}{l}0 \\
15\end{array}$ & $\begin{array}{l}0 \\
15\end{array}$ & 14 & $\begin{array}{l}2 \\
13\end{array}$ & $\begin{array}{l}3 \\
12\end{array}$ & $\begin{array}{l}6 \\
99\end{array}$ & 0.06 \\
\hline $37^{\circ} \mathrm{C}$ & $\begin{array}{l}\text { Dead } \\
\text { a live }\end{array}$ & $\begin{array}{l}0 \\
15\end{array}$ & $\begin{array}{l}0 \\
15\end{array}$ & $\begin{array}{l}0 \\
15\end{array}$ & $\begin{array}{l}0 \\
15\end{array}$ & $\begin{array}{l}0 \\
15\end{array}$ & 14 & $\begin{array}{l}2 \\
13\end{array}$ & $\begin{array}{l}3 \\
102\end{array}$ & 0.029 \\
\hline $40^{\circ} \mathrm{C}$ & $\begin{array}{l}\text { Dead } \\
\text { a live }\end{array}$ & $\begin{array}{l}0 \\
15\end{array}$ & $\begin{array}{l}0 \\
15\end{array}$ & $\begin{array}{l}0 \\
13\end{array}$ & $\stackrel{4}{11}$ & $\begin{array}{l}6 \\
9\end{array}$ & $\begin{array}{l}9 \\
6\end{array}$ & $\begin{array}{l}12 \\
3\end{array}$ & $\begin{array}{l}33 \\
72\end{array}$ & 0.45 \\
\hline Group $40^{\circ} \mathrm{C}$ & & & & & & & & & & \\
\hline $34^{\circ} \mathrm{C}$ & $\begin{array}{l}\text { Dead } \\
\text { a live }\end{array}$ & $\begin{array}{l}0 \\
15\end{array}$ & $\begin{array}{l}0 \\
15\end{array}$ & $\begin{array}{l}0 \\
15\end{array}$ & $\begin{array}{l}0 \\
15\end{array}$ & $\begin{array}{l}2 \\
13\end{array}$ & $\begin{array}{l}3 \\
12\end{array}$ & $\begin{array}{l}5 \\
10\end{array}$ & $\begin{array}{l}10 \\
95\end{array}$ & 0.11 \\
\hline $37^{\circ} \mathrm{C}$ & $\begin{array}{l}\text { Dead } \\
\text { a live }\end{array}$ & $\begin{array}{l}0 \\
14\end{array}$ & $\begin{array}{l}0 \\
14\end{array}$ & $\begin{array}{l}0 \\
14\end{array}$ & $\begin{array}{l}0 \\
14\end{array}$ & $\begin{array}{l}2 \\
12\end{array}$ & $\begin{array}{l}4 \\
10\end{array}$ & $\begin{array}{l}9 \\
15\end{array}$ & $\begin{array}{l}15 \\
85\end{array}$ & 0.18 \\
\hline $40^{\circ} \mathrm{C}$ & $\begin{array}{l}\text { Dead } \\
\text { a live }\end{array}$ & $\begin{array}{l}0 \\
13\end{array}$ & $\begin{array}{l}0 \\
13\end{array}$ & $\begin{array}{l}0 \\
13\end{array}$ & $\begin{array}{l}2 \\
11\end{array}$ & $\begin{array}{l}5 \\
8\end{array}$ & $\begin{array}{l}9 \\
4\end{array}$ & $\begin{array}{l}12 \\
1\end{array}$ & $\begin{array}{l}28 \\
63\end{array}$ & 0.44 \\
\hline
\end{tabular}

